Institute of $\mathbf{F}_{\text {ood and }} \mathbf{A}_{\text {gricultural }} \mathbf{S}_{\text {ciences }}$

\title{
2003 Handbook of Employment Regulations Affecting Florida Farm Employers and Workers: Unemployment Compensation [Federal and State] ${ }^{1}$
}

Leo C. Polopolus, Michael T. Olexa, Fritz Roka, and Carol Fountain ${ }^{2}$

\section{Purpose}

This program is intended to benefit persons unemployed through no fault of their own.

\section{Who Must Comply}

Any farmworker employer who has in the current calendar year or in the preceding calendar year:

- A payroll of at least $\$ 10,000$ in any calendar quarter.

- Five or more employees for some portion of a day in twenty or more weeks during the year.

\section{Responsible Employer}

Depending on the circumstances, the farm operator or labor contractor may be the employer. The factors used to determine whether or not an individual is an independent contractor (i.e., the employer) include:

- What is the extent of control which the business may exercise over the details of the work?

- Is the worker in a distinct occupation or business?

- Is this type of work usually done under the direction of the employer or by a specialist without supervision?

1. This is EDIS document FE420, a publication of the Department of Food and Resource Economics, Florida Cooperative Extension Service, Institute of Food and Agricultural Sciences, University of Florida, Gainesville, FL. Published July 2003. This information is included in Circular 1200, Handbook of Employment Regulations Affecting Florida Farm Employers and Workers. First published February 1992 as Circular 1043 . Revised December 2002 as Circular 1200. Please visit the EDIS website at http://edis.ifas.ufl.edu.

2. Leo C. Polopolus, Professor Emeritus, Department of Food and Resource Economics, University of Florida, Gainesville, FL; Michael T. Olexa, Professor, Department of Food and Resource Economics, University of Florida, Gainesville, FL; Fritz Roka, Associate Professor, Department of Food and Resource Economics, Southwest Florida Research and Education Center, Immokalee, FL; and Carol Fountain, Assistant Editor, Department of Food and Resource Economics, University of Florida, Gainesville, FL; Florida Cooperative Extension Service, Institute of Food and Agricultural Sciences, University of Florida, Gainesville, FL.

This document is designed to provide accurate, current, and authoritative information on the subject. However, since the laws, administrative rulings, and court decisions on which it is based are subject to constant revision, portions of this publication could become outdated at any time. This publication is distributed with the understanding that the authors are not engaged in rendering legal or other professional advice, and the information contained herein should not be regarded as a substitute for professional advice. For these reasons, the utilization of these materials by any person constitutes an agreement to hold harmless the authors, the Institute of Food and Agricultural Sciences, and the University of Florida for any liability claims, damages, or expenses that may be incurred by any person as a result of reference to or reliance on the information contained in this publication.

The Institute of Food and Agricultural Sciences is an equal opportunity/affirmative action employer authorized to provide research, educational information and other services only to individuals and institutions that function without regard to race, color, sex, age, handicap, or national origin. For information on obtaining other extension publications, contact your county Cooperative Extension Service office. Florida Cooperative Extension Service/Institute of Food and Agricultural Sciences/University of Florida/Christine Taylor Waddill, Dean. 
- Is the skill required?

- Who supplies the place of work, tools, and materials?

- What is the length of time employed?

-What is the method of payment?

- Do the parties believe it is an independent relationship?

- The work part of the regular business of the employer?

- Is the principal in business?

The FARM OPERATOR is the employer under these circumstances:

- The worker is an employee of the farm operator under master/servant common law rules.

- The worker is furnished by the labor contractor but is not treated as an employee of the labor contractor (i.e., the labor contractor is acting on behalf of the farm operator rather than as an employer).

- The labor contractor has entered into a written agreement with the farm operator under which the labor contractor is designated as an employee of the farm operator.

The LABOR CONTRACTOR is the employer under these circumstances:

- The labor contractor holds valid certification of registration under the Migrant and Seasonal Agricultural Worker Protection Act of 1983.

- Substantially all crew members operate or maintain tractors, mechanized harvesting or crop-dusting equipment, or other mechanized equipment provided by the labor contractor.

- The worker is not an employee of any person under master/servant common law rules.

\section{Farm Related Exempt Employment:}

- Farmworker for an exempt employer (See Who Must Comply.)
- Certain students working for credit on a program combining academic instruction with work experience (work-study program).

- Service performed for a son, daughter, or spouse or by a child under age eighteen for his or her father or mother. When the employing unit is a partnership, the exempt relationship must exist with all partners.

- Work performed on a fishing vessel under ten net tons.

- Work performed by temporary H-2A workers (unless workers apply for and are granted a different alien registration status).

\section{Employers Must}

Pay unemployment compensation tax on the first $\$ 7,000$ of annual payroll earnings for each employee. There are two parts to the tax: federal and state.

The effective FEDERAL tax is 0.8 percent of the first $\$ 7,000$ of annual payroll of each employee. (The actual federal tax is 6.2 percent less a credit of 5.4 percent if the employer pays the state tax by January 31 st of the following year.)

The STATE tax will vary depending on the experience rating of the individual farm employer and the timeliness of tax payments. Farm employers without an experience rating will pay 2.0 percent of the first $\$ 7,000$ of the annual payroll of each employee for calendar year 1998 only. Unless the state legislature amends the current law, new employers will then pay a tax rate of 2.7 percent of covered payroll for the next six quarters. At the end of the tenth calendar quarter, the rating process will be completed and taxes paid in the eleventh quarter and subsequent quarters will be based on the experience rating.

Experience ratings are recalculated annually thereafter. Annual rate notices are mailed to all employers on or before March 15th of the applicable year. The current maximum tax rate payable in Florida is 5.4 percent and the minimum tax rate is 0.1 percent. 


\section{Posting Requirements}

Employers must display, in a place where all employees can see it, the poster "To Employees" (LES Form BUC-83 in English or LES Form BUC-83S in Spanish).

\section{Record-Keeping Requirement}

Employers must have records available for inspection at any reasonable hour during the business day and maintain records for a period of five calendar years.

\section{Employee Eligibility}

In addition to being unemployed, able and available for work, and not subject to any of the disqualifications listed below, a claimant must have the necessary wage credits during the base period.

Base period. The base period is the first four of the last five completed calendar quarters prior to the quarter in which a claim is filed.

Wage credits. An individual must have wages in two or more calendar quarters during the base period, which is the first four of the last five completed calendar quarters prior to the effective date of the claim. The total base period wages must be at least $\$ 3,400$. Also, the total base period wages must be at least 1.5 times the wages in the quarter with the highest earnings.

\section{Weekly Benefits}

The weekly benefit amount to which a claimant is entitled is one-half the average weekly wage but not more than $\$ 275$ for benefit years beginning January 1, 1998. The maximum benefit amount can only be changed by the Legislature.

\section{Employee Claims}

Employees do not pay for unemployment insurance. This cost is borne by the employer. Eligible unemployed farmworkers may file for benefits at the local office of the Division of Unemployment Compensation. (See Responsible Agency.)
A farmworker may not be eligible for benefits if it is found that he or she:

- Voluntarily quits his or her job without good cause attributable to his or her employer.

- Was discharged for misconduct connected with his or her work, including drug use as evidenced by a positive, confirmed drug test.

- Fails to apply for or accept suitable work.

- Is unemployed due to participation in a labor dispute.

- Fails to disclose required information on a benefit claim. Willful misrepresentation is also cause for fine and imprisonment.

- Is receiving or is eligible to receive a retirement income from a base period employer.

- Is receiving or is seeking employment benefits under an unemployment compensation law of another state or the United States.

- Is an illegal alien.

- Was terminated from employment for violation of any criminal law punishable by imprisonment.

- Was terminated for unsatisfactory work performance during an established probationary period of employment.

\section{Additional Information}

- LES UC Bulletin 1, Unemployment Insurance for Workers Under Florida Unemployment Compensation Law (Revised 4/88).

- LES UC Bulletin 2, Florida Employer, Information on the Florida Unemployment Compensation Law (Revised 8/90).

- Division of Unemployment Compensation, Florida Unemployment Compensation, Employer Handbook (Revised 8/90). 


\section{Other Information}

- Labor Bulletin No. 364, Florida Fruit and Vegetable Association, October 1977.

- Labor Bulletin No. 413, Florida Fruit and Vegetable Association, March 1983.

- Chapter 443, Florida Statutes.

\section{Responsible Agency}

For employer tax information, contact

Florida Department of Revenue

Tax Information Services

5050 West Tennessee Street

Tallahassee, FL 32399-0100

(850) $922-4825$ or

dial toll-free 1(800) 482-8293

http://sun6.dms.state.fl.us/dor/contact.html

For employee information about unemployment compensation, contact

Florida Agency for Workforce Innovation

Unemployment Compensation

Post Office Drawer 5350

Tallahassee, FL 32314-5350

(850) 921-3372

http://www2.myflorida.com/awi/unemployment

http://www2myflorida.com/

awicontacts.html\#unemployment

http://www.floridajobs.org/onestop/

onestopdir.index.htm

Local Unemployment Compensation offices are located in Clearwater, Cocoa, Daytona Beach, Fort Lauderdale, Fort Myers, Fort Pierce, Gainesville, Homestead, Hudson, Jacksonville, Lakeland, Miami, North Dade, South Dade, Naples, Ocala, Orlando,
Panama City, Pensacola, Sarasota, South Orlando, St. Petersburg, Tallahassee, Tampa and West Palm Beach. 